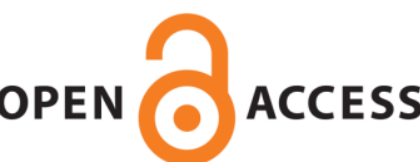

UWS Academic Portal

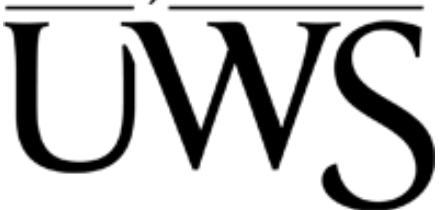

\title{
Effect of a water conditioner on ornamental fish behaviour during commercial transport
}

Vanderzwalmen, Myriam; Edmonds, Elizabeth; Carey, Peter; Snellgrove, Donna; Sloman, Katherine A.

Published in:

Aquaculture

DOI:

10.1016/j.aquaculture.2019.734486

Published: 01/01/2020

Document Version

Peer reviewed version

Link to publication on the UWS Academic Portal

Citation for published version (APA):

Vanderzwalmen, M., Edmonds, E., Carey, P., Snellgrove, D., \& Sloman, K. A. (2020). Effect of a water conditioner on ornamental fish behaviour during commercial transport. Aquaculture, 514, [734486].

https://doi.org/10.1016/j.aquaculture.2019.734486

\section{General rights}

Copyright and moral rights for the publications made accessible in the UWS Academic Portal are retained by the authors and/or other copyright owners and it is a condition of accessing publications that users recognise and abide by the legal requirements associated with these rights.

Take down policy

If you believe that this document breaches copyright please contact pure@uws.ac.uk providing details, and we will remove access to the work immediately and investigate your claim. 


\section{Effect of a Water Conditioner on}

\section{Ornamental Fish Behaviour During}

3 Commercial Transport.

4 Myriam Vanderzwalmen $^{\mathrm{a}}$, Elizabeth Edmonds ${ }^{\mathrm{a}}$, Peter Carey $^{\mathrm{b}}$, Donna Snellgrove ${ }^{\mathrm{c}}$ and Katherine A.

5 Sloman $^{\mathrm{a}}$

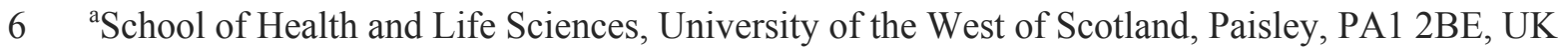

$7 \quad{ }^{b}$ Pets at Home, Handforth, Cheshire, UK

$8{ }^{\mathrm{c}}$ WALTHAM ${ }^{\circledR}$ Centre for Pet Nutrition, Waltham-on-the-Wolds, Freeby lane, LE14 4RT,

9 Leicestershire, UK

correspondence

Myriam Vanderzwalmen, School of Health and Life Sciences, University of the West of Scotland, 


\section{Abstract}

16 Millions of ornamental fishes undergo transport every year during which they experience high levels

17 of stress and prolonged recovery. Studies aiming to refine welfare during transport have generally focused on maintaining water quality to minimise stress, with far less consideration of whether the addition of water conditioners containing herbal extracts to transport water could provide additional stress reduction beyond that obtained by maintaining good water quality. No study has previously tested this on a commercial scale. The aim of this study was to test the effect of Stress Coat ${ }^{\circledR}$, a commercially-available water conditioner which contains Aloe vera, on fish health and behaviour during commercial transport. First, we tested the effect of the water conditioner on the behaviour of guppies (Poecilia reticulata) post-transport in a simulated transport in the laboratory (bags with Stress Coat $^{\circledR} n=6$, control bags: $n=6$ ). In a second experiment, we added water conditioner to the shipment water of variatus platy (Xiphophorus variatus) for regional transport from a UK wholesaler to UK retail stores ( $<8 \mathrm{~h}$ transport time) (bags with Stress Coat ${ }^{\circledR} n=11$, control bags: $\left.n=11\right)$. Finally, the water conditioner was added to the shipment water of variatus platy for international transport from a farm in South-East Asia to a UK wholesaler ( $>30 \mathrm{~h}$ transport) (bags with Stress Coat ${ }^{\circledR} n=16$, control bags: $\mathrm{n}=16)$ followed by a second transport by road to local retailers $(<9 \mathrm{~h})$ with no addition of Stress Coat $^{\circledR}$. Behaviour was monitored following the simulated transport. Water quality, behaviour, mortality and visible injuries of fish post-transport were monitored following both the regional and international transports. The effects of the water conditioner were variable between studies, but overall it reduced levels of erratic swimming and reduced biting behaviours following the simulated and international transport. The water conditioner did not significantly affect water quality, mortality or visible injuries post-transport and mortality was low throughout. Overall, adding Stress Coat ${ }^{\circledR}$ to the transport water of ornamental fishes appears to improve behavioural indicators of welfare, in particular reducing the occurrence of erratic swimming and biting behaviours. 
Highlights:

- The present study tested the effect of a water conditioner, Stress Coat ${ }^{\circledR}$, on fish behaviour during simulated, regional and international commercial transports.

- The water conditioner reduced biting behaviour post-transport for both simulated and international transports.

- Exposure to the water conditioner both during a regional and international transport resulted in reduced erratic swimming behaviour on arrival at retail stores.

- There was no detectable effect of the water conditioner on mortality or visible injuries.

51 Funding: This work was supported by Mars Petcare, UK 


\section{1. Introduction}

An estimated 2 billion live ornamental fishes are transported annually (Monticini, 2010). During packing, transport and recovery fishes can experience high levels of stress and their welfare can become compromised leading to reduced immune resistance (Portz et al., 2006; Sampaio and Freire, 2016) and high mortality (estimated to range from $<5 \%$ for freshwater fishes to $80 \%$ for wild caught marine fishes) (Rubec and Cruz, 2005). Within the ornamental trade, sedation with anaesthetics is often used during transport to try to reduce stress experienced by fishes (Cupp et al., 2017; Harmon, 2009; Lim et al., 2003), however, there is potential for chemical based anaesthetics to increase stress before reducing it (Ims, 2011; Readman et al., 2013, Souza 2019). Alternatively, a range of herbal extracts (essential oils and methanolic extracts) have been tested for their sedating properties in fishes and found to be effective in reducing transport-associated stress when added to the transport water (Vanderzwalmen et al., 2019). Clove oil (Syzygium aromaticum) and Lippia alba (common names include: bushy matgrass and pitiona) are the most studied extracts (Azambuja et al., 2011; Becker et al., 2012; Javahery et al., 2012). Clove oil is an effective fish sedative and has been found to lower primary and secondary physiological stress responses during transport (Becker et al., 2013; Inoue et al., 2005; Iversen et al., 2009). However, prolonged exposure (48 h) was found to have a narrow safety margin in the cichlid Haplochromis obliquidens (Kaiser et al., 2006). Lippia alba has been found to reduce ion loss and improve redox state following transport in silver catfish (Rhamdia quelen) (Azambuja et al., 2011; Becker et al., 2012) but its benefits are dose dependent as higher doses $\left(>20 \mu 11^{-1}\right)$ have been found to increase plasma cortisol and induce hepatic oxidative stress (Becker et al., 2016; Salbego et al., 2014). Due to the narrow safety margins of sedatives and the risks of an initial stress reaction to sedative compounds, non-sedating herbal-extracts could prove to be a more efficient alternative to reduce transport-associated stress. 
Herbal extracts which do not have known sedative properties have also been tested for their ability to reduce stress during transport, either as dietary supplements or as water conditioners. For example, Aloe vera (also known as $A$. barbadensis) is a succulent plant that has been used for over 2000 years for its therapeutic properties in humans (Christaki and Florou-Paneri, 2010; Radha and Laxmipriya, 2015). The leaf is composed of three layers: the rind, a layer of yellow sap, and the inner gel (Christaki and Florou-Paneri, 2010). The gel is composed of water (98.5-99.5\%) and over 75 compounds (Christaki and Florou-Paneri, 2010; Radha and Laxmipriya, 2015). These compounds include water-soluble and fat-soluble vitamins, minerals, enzymes, polysaccharides, phenolic compounds and organic acids (Choi and Chung, 2003; Hamman, 2008) thus the health benefits of $A$. vera are likely to be a result of various compounds working in synergy (Hamman, 2008; Radha and Laxmipriya, 2015). Aloe vera is commonly used in traditional human medicine to aid various ailments (Radha and Laxmipriya, 2015) and has also been researched for its potential benefits to aquaculture (Alishahi et al., 2010; Gabriel et al., 2015a, 2015b; Zanuzzo et al., 2015a). Most research on the effects of $A$. vera in fishes has focused on supplementing diets with $A$. vera extracts, with concentrations ranging between 1 and $40 \mathrm{~g} \mathrm{~kg}^{-1}$ of $A$. vera added to the diets of cultured fishes (e.g. common carp (Cyprinus carpio); steelhead trout (Oncorhynchus mykiss); tilapia (Oreochromis niloticus)) for 4-8 weeks (Alishahi et al., 2010; Gabriel et al., 2015b ; Zanuzzo et al., 2015a). The majority of these studies have focussed on potential benefits for haemato-biochemical parameters and immune response following a bacterial challenge. Overall, supplementing diets with $A$. vera results in improved haemato-biochemical parameters, such as an increase in serum lysozyme activity, red blood cells, hematocrit, haemoglobin, white blood cells, lower basal plasma cortisol rate, serum triacylglycerol and enhanced antioxidant enzymes activities (Alishahi et al., 2010; Gabriel et al., 2015a, 2015b; Zanuzzo et al., 2015a).

Water conditioners containing either pure herbal extracts or extracts combined with other products are commercially available and may have the potential to reduce transport-associated stress in ornamental fishes. One example is Stress Coat ${ }^{\circledR}$ which is sold under the API brand name, manufactured by Mars Fishcare, North America, Inc. and contains 1-10\% A. vera (reported as $A$. 
barbadensis on the material safety data sheet). Other constituents include water (>80\%) and other non-hazardous ingredients (trade protected) (1-10\%) (Mars Fishcare Inc., 2014). This water conditioner has been developed to reduce the effects of potentially stressful procedures such as routine husbandry practices (e.g. handling, water changes) and transport by removing harmful chemicals from the water, promoting healing of surface wounds, and restoring lost mucus. While the use of Stress Coat ${ }^{\circledR}$ is mentioned in the literature as part of routine husbandry practice (Colburn et al., 2008; Earley et al., 2006; Harnish et al., 2011; Wong et al., 2015), no published peer-reviewed study has been found testing the effect of Stress Coat ${ }^{\circledR}$ on fishes. The aim of this study was to test the potential benefits of adding Stress Coat ${ }^{\circledR}$ to transport water of ornamental fishes. Firstly, the effects of the water conditioner during a simulated transport study using guppies (Poecilia reticulata) in the laboratory were investigated, followed by two studies testing the effects of the water conditioner on variatus platy (Xiphophorus variatus) during commercial transport. For this, Stress Coat ${ }^{\circledR}$ was added to either the regional $(<9 \mathrm{~h})$ or international $(>30 \mathrm{~h})$ component of a commercial transport. Our hypothesis was that the addition of the water conditioner to transport water would reduce stressrelated behaviours following transport and potentially improve fish health and welfare.

\section{Methods}

\section{Simulated Laboratory Transport}

Adult guppies (Poecilia reticulata; mixed sex; 2.9 and $4.3 \mathrm{~cm}$ in length for males and females respectively) from an existing laboratory stock (originally obtained from a home aquarium supplier in the greater Glasgow area) at the University of the West of Scotland were quarantined for two weeks and then held in groups of nine, in six 101 glass tanks with environmental enrichment, on a recirculating system with charcoal, biological and UV filtration (temperature: $23.5 \pm 0.02^{\circ} \mathrm{C} ; \mathrm{pH}$ : 7.17 \pm 0.03 ; dissolved oxygen: $7.47 \pm 0.03 \mathrm{mg}^{-1}$; mean \pm SEM). Fish were held in the laboratory for 10 weeks prior to experiments on a $12 \mathrm{~h}$ light: dark photoperiod and fed to satiation daily on a pellet diet (API Tropical mini pettets, Mars Fishcare, UK). Partial water changes were made to the recirculating 
system on a weekly basis, and throughout ammonia, nitrate and nitrite concentrations remained $<$ $0.25,5$ and $0.25 \mathrm{mg}^{-1}$ respectively.

Following the 10 week acclimation period, guppies were subjected to a $1 \mathrm{~h}$ transport stress.

Fish were transported in groups of three in transparent polyethylene bags $(15.2 \times 22.9 \mathrm{~cm})$ containing $150 \mathrm{ml}$ of water from the recirculating system. One bag of three fish from each tank was treated with Stress Coat ${ }^{\circledR}$ and one bag of three fish from each tank was kept as a control ( $\mathrm{n}=6$ bags per treatment). The other three fish in the tank were not used in this study. The concentration of Stress Coat ${ }^{\circledR}$ used was $260 \mu 11^{-1}$, which is the maximum recommended concentration to 'replace slime coat and repair damage to skin and fins'. Bags were sealed with air in the space at the top of the bag and placed into a polystyrene box with a lid $(310 \times 215 \times 232 \mathrm{~mm})$. The box was then walked around the lab continuously for $1 \mathrm{~h}$. Following the transport stress, fish were transferred by net in their groups of three to a 101 tank where their behaviour was filmed for $1 \mathrm{~h}$ (see Behavioural Analysis). Fish were then returned to stock and later re-homed.

\section{Addition of Water Conditioner During Regional Transport}

Variatus platy (Xiphophorus variatus; mixed sex; $~ 3.5 \mathrm{~cm}$ in length) were reared in

Singapore and transported to a UK ornamental fish wholesaler based in the Glasgow area using standard commercial practices (see below for details) and housed at the wholesaler for 1 week. After the recovery period, bags of variatus platy were tracked from the wholesaler to six retail stores in the greater Glasgow area (Scotland, UK) (journey distance range: 9.8-25 km). The time from packing the fish at the wholesaler until the fish were placed in their recovery tank at the retail store varied between stores depending on the delivery route (range: 4-8 h). For packing, fish were placed into transparent polyethylene bags $\left(25.5 \times 35 \mathrm{~cm}, 5-10\right.$ fish $\left.^{-1}\right)$, which were topped up with pure oxygen, sealed (airtight with a metal wire), double bagged and placed into a packing box along with a variable number of other bags. Eleven bags containing platys with Stress Coat ${ }^{\circledR}$ and 11 control bags of platys were tracked. Bags were tracked in pairs, where two bags were transported from the wholesaler to a retail 
store on each journey, one as a control and one containing the water conditioner and were paired for statistical analyses. This accounted for the fact that bags were tracked to different stores, and that exact transport times were dependent on traffic delays and delivery routes. All bags were tracked within a 4-week period. The concentration of Stress Coat ${ }^{\circledR}$ used was $125 \mu 11^{-1}$, which followed manufacturer recommendations for stressful conditions, and was half the dose used in the laboratory experiment. The addition of this quantity of water conditioner represents a more financially viable option if adopted on a large commercial scale. On arrival at the stores, control bags and those containing water conditioner were placed into separate tanks on a recirculating system for recovery. Water quality in the bags was measured on arrival at the stores and a water sample $(1.5 \mathrm{ml})$ taken for further analysis (see Water Quality below). Bags were then floated for $30 \mathrm{~min}$ in the tank, first sealed (to allow temperatures to equalise) and then opened to slowly mix bag water with tank water for 30 min before releasing the fish into the tank. Water quality measurements were repeated on the tanks at days 1, 2 and 5 of recovery at the stores. Fish were videoed for 30 min within their transport bags on arrival at the store, and then again within their tanks on days 1,2 and 5 (see Behavioural Analysis below). Any visible body or fin injuries were noted from the videos used for behavioural analysis. Any mortality was recorded on arrival at the store and then daily at 08.00 and 20.00 by staff at the retail stores and removed from the tank. Mortality was then expressed as a percentage based on the original number of fish in the bag. Fish were fed twice daily and kept under a $12 \mathrm{~h}$ light/dark regime.

\section{Addition of Water Conditioner During International Transport}

Thirty two bags (eight bags of four different colour strains) of variatus platy (X. variatus; mixed sex; $\sim 3.5 \mathrm{~cm}$ in length) were tracked from a farm in Singapore to a UK ornamental fish wholesaler in the Glasgow area. Bags were tracked in pairs where, for each strain, two bags were transported from the farm to the wholesaler on each journey, one as a control and one containing Stress Coat ${ }^{\mathbb{B}}\left(125 \mu 11^{-1}\right)$ and were paired for statistical analyses. Prior to transport to the UK, food was withheld for $24 \mathrm{~h}$ at the farm and then the fish were packed in transparent polyethylene bags with 
rounded corners containing 3.51 of water $\left(35.5 \times 54 \mathrm{~cm}\right.$ bags, 45 fish $\left.{ }^{-1}\right)$, with $25 \mathrm{ml}$ of liquid zeolite

184 (SeaChem $^{\mathrm{TM}}$ ) added to each bag. Bags were topped up with oxygen and air-tight sealed, double bagged and placed into a packing box along with a variable number of other bags. The boxes were then air shipped to a UK airport where they passed through customs before undergoing a $\sim 4$ h road transport to the wholesaler (total transport $>30 \mathrm{~h}$ ). On arrival at the wholesaler, each bag was allocated to a separate static water tank, and bags were floated in the water before water from the bag and the tank were allowed to mix as described above. Fish were held in tanks at the wholesaler for at least 7 days before being transported to retail stores. At the wholesaler, fish were fed three times daily and kept under a 10:14 light/dark regime. They were checked three times a day by staff at the wholesaler and any mortality noted. Water quality and behavioural data were collected on arrival at the wholesaler and on day 5 of recovery at the wholesaler. Any visible body or fin injuries were noted from the videos used for behavioural analysis. Following recovery time at the wholesaler, fish were re-bagged for road transport to the same retail stores as for the regional transport (transport time 4-8 h). No water conditioner was added at this stage of transport. Fish from each treatment (control and Stress Coat ${ }^{\circledR}$ during international transport) were packed separately for transport to the store and were placed in different tanks for recovery at the store. Water quality and behavioural data were collected on arrival at the retail store as in the regional transport study and on day 5 of recovery. Injuries were recorded in the same way as before and mortality was recorded twice daily by staff at the retail stores. Mortality was expressed throughout the study as a percentage of the original number of fish in the bag in which it was transported from Singapore, to ensure per cent mortality was comparable across the stages of transport.

\section{Data collection}

\section{Water Quality}

For the regional and international transport studies, water $\mathrm{pH}$, oxygen and temperature were measured at each sampling point. $\mathrm{pH}$ was measured using a Mettler Toledo FiveGo $\mathrm{pH}$ meter. 
Temperature $\left({ }^{\circ} \mathrm{C}\right)$ and dissolved oxygen (DO) were measured with a LDO101 probe and an HQ30d meter. A water sample $(1.5 \mathrm{ml})$ was collected and frozen using ice packs for later analysis of ammonia concentrations; samples were stored at $-20^{\circ} \mathrm{C}$ until they were processed. Total ammonia nitrogen levels were quantified using a microplate colorimetric procedure (Bower and Holm-Hansen, 1980). Standards were made by a dilution of $1 \mathrm{mM}$ ammonium chloride. Standards and samples were run in triplicate. The un-ionised ammonia $\left(\mathrm{NH}_{3}\right)$ content was calculated from the total ammonia nitrogen values, the $\mathrm{pH}$ and temperature $\left({ }^{\circ} \mathrm{C}\right)$ (California Water Boards Agency, 2011).

\section{Behavioural analysis}

For the laboratory studies, post-transport behaviours were recorded for $1 \mathrm{~h}$ using a Panasonic SDR-S50 video camera. Each 101 tank contained environmental enrichment; one plastic plant took up one quarter of the back half of the tank, and the other back quarter contained a plastic shelter. The front half of the tank was left empty. Food was introduced into the front half of the tank after the first 30 min. Video footage was analysed for erratic swimming, aggressive chases and actual bites between fish (Table 1). The total number of occurrences of these behaviours performed by all fish within the tank was counted. A subsample $(\sim 10 \%)$ of videos were analysed blind by an additional observer with a high inter-observer reliability (Kendall's W coefficient: $0.99, \mathrm{p}<0.01$ ).

For the regional and international transports, video recordings (30 $\mathrm{min})$ were made using cameras (WiMiUS 4K 16MP Action, GoPro Hero 4 \& 5) mounted on monopods and set at $720 \mathrm{P}$ (progressive scan) and $120 \mathrm{fps}$ (frames per seconds). Upon arrival at the retail stores, behavioural recordings were made when the fish were still in the transport bag. During recovery, at both the wholesaler and retail stores, video recordings were made at random times of the day but not within $1 \mathrm{~h}$ before or after feeding. Behavioural Observation Research Interactive Software (BORIS) (Friard and Gamba, 2016) was used to analyse behaviours displayed by the fish (Table 1). Randomly selected individual fish were tracked for $3 \mathrm{~min}$, and this was repeated consecutively from the start to the end of the video such that 10 individuals were tracked. Displayed behaviours for each focal fish within the 
video were totalled to obtain a behaviour score per bag or tank. However, on arrival at the wholesaler

236 following international transport, it was not possible to track a focal fish for as long as 3 min due to

237 the high number of fish in the bag; therefore videos of the bags were watched for the full duration and

238 any occurrence of the behaviours in Table 1 by any fish were recorded to give a total score for the bag

239 for the $30 \mathrm{~min}$.

240 Table 1. Ethogram of the behaviours recorded.

\begin{tabular}{|c|c|c|}
\hline Behaviour & Description & Relation to welfare \\
\hline Chases & $\begin{array}{l}\text { Occurrence of fish chasing } \\
\text { one another. }\end{array}$ & $\begin{array}{l}\text { Aggressive interaction has been associated } \\
\text { with elevated stress (Vera Cruz and Brown, } \\
\text { 2007; Kadry and Barreto, 2010; Saxby et al. } \\
\text { 2010; Gronquist and Berges, 2013). }\end{array}$ \\
\hline Bites & $\begin{array}{l}\text { Occurrence of fish nipping } \\
\text { or biting one another. }\end{array}$ & $\begin{array}{l}\text { Biting can cause injuries and may lead to } \\
\text { mortality (Pitcher, 2012; Håstein, 2004; } \\
\text { Noble et al., 2012; Kalueff et al. 2013). }\end{array}$ \\
\hline Erratic swimming & $\begin{array}{l}\text { Occurrence of rapid } \\
\text { swimming and direction } \\
\text { change. }\end{array}$ & $\begin{array}{l}\text { Erratic swimming is an indicator of elevated } \\
\text { stress, distress or pathogenic condition and } \\
\text { may be used as a sign of reduced welfare } \\
\text { (Conte, 2004; Håstein, T., 2004, White et al. } \\
\text { 2017). }\end{array}$ \\
\hline Ventilation rate & $\begin{array}{l}\text { Measured by visually } \\
\text { counting } 20 \text { successive } \\
\text { opercular or buccal } \\
\text { movements, measuring the } \\
\text { elapsed time and then } \\
\text { calculating the frequency } \\
\text { per minute (based on }\end{array}$ & $\begin{array}{l}\text { Ventilation rate can increase as a result of } \\
\text { aquaculture procedures or stressors and is a } \\
\text { highly sensitive mechanism involved in stress } \\
\text { coping strategies (Barreto and Volpato, 2004, } \\
\text { 2011; Martins et al., 2012). }\end{array}$ \\
\hline
\end{tabular}


Alvarenga and Volpato,

1995).

Any visible body and fin injuries were recorded from the videos used for behavioural analysis. During the behavioural analysis, visible injuries were recorded for each focal fish and given a score for severity. Injuries to fins were recorded as follows: (0) no visible injury; (1); small section of fin missing; (2) large section of fin missing or shortening of the fin; (3) fin missing. Body injuries were recorded based on the following criteria: (0) no visual injuries; (1) single minor non-lifethreatening injury; (2) multiple minor non-life threatening injuries; (3) major life-threatening injury (Deng et al. 2005; Neitzel et al. 2000, 2004). The scores for fin injury and body injury were combined for all 10 focal fish observed in the same video to obtain one overall bag or tank injury score.

\section{Statistical Analyses}

The software R and Rstudio 1.1.414 were used to carry out statistical analyses (R Studio Team, 2016; R Core Team, 2018) according to Bolker et al. (2009). A Kendall's w test of concordance was carried out on a subset of random videos with the DescTools package (Signorell and et al., 2019) to test for inter-observer reliability. Response variables recorded as percentages were transformed using the arcsine function. Data distribution was visually determined by plotting the response variables by their frequency of occurrence using the ggplot2 package (Wickham, 2016). For normally distributed response variables, a general linear mixed model was carried out using the lmer function from the lme4 package (Bates et al., 2015). Treatment and transport stage (and the interaction of the two) were set as explanatory variables (treatment only for the simulated transport). For the simulated transport laboratory study, tank number was set as a random variable. For the regional and international transport studies, store and pair number were set as random variables (strain was initially included as 
an a explanatory variable in the international transport study but was found to be non-significant and therefore removed to reduce complexity of the models). For response variables not normally distributed, a general linear mixed model was carried out and the distribution of the residuals was determined visually by plotting a histogram of the residuals by their frequency of occurrence using ggplot2 and by plotting a Q-Q plot of the theoretical quantiles by the sample quantiles and adding a normality line using the stats package (R Core Team, 2018). For response variables with nonnormally distributed residuals, a generalised linear mixed model was carried out using poisson family from the lme4 package with the same variables as above (Bates et al., 2015). As necessary, the data were transformed using the log or square root function to obtain normally distributed residuals. The best fit model was selected by disregarding explanatory variables that did not significantly improve the fit of the model using the summary function from lme4 (Bates et al., 2015). The significance of the covariates was tested using $t$-test for the simulated transport study and an ANOVA (anova function in the nlme package and the Anova function in the car package) for the regional and international transport studies (Fox and Weisberg, 2011; Pinheiro et al., 2018). A post-hoc Tukey test was carried out using the lsmeans package for the regional and international transports (Lenth, 2017). The figures were created using the ggplot2 package (Wickham, 2016).

\section{Ethical approval}

This study was approved by the University of the West of Scotland and WALTHAM Centre for Pet Nutrition animal welfare and ethics review boards and the simulated laboratory transport was carried out under a Home Office Project Licence (PPL 70/8539).

\section{Results}



$(\mathrm{t}=7.962, \mathrm{df}=9.592, \mathrm{p}<0.001$; Fig. 1). There was no significant difference in chasing behaviour $(\mathrm{t}=0.714, \mathrm{df}=7.215, \mathrm{p}=0.498)$ or erratic swimming behaviour between fish transported with or without Stress Coat $(\mathrm{t}=1.346, \mathrm{df}=9.264, \mathrm{p}=0.21)$. water conditioner $\left(F_{1,69}=16.686, p<0.001\right.$; Fig. 2$)$ and time $\left(F_{3,69}=235.345, p<0.001\right.$; Fig. 2$)$ with a significant interaction between the two factors $\left(F_{3,69}=17.97, p<0.001\right.$; Fig. 2). Overall, erratic swimming behaviour was greatest on arrival at the retail store and reduced during the recovery period. Fish that were transported with the water conditioner had reduced erratic swimming on arrival at the retail store compared to controls (Fig. 2). Chasing behaviour significantly increased throughout recovery at the stores $\left(\mathrm{F}_{3,69}=6.993, \mathrm{p}<0.001 ;\right.$ Fig. 3$)$ and was higher in the fish transported with water conditioner on days 1 and 2 of recovery $\left(\mathrm{F}_{1,69}=5.588, \mathrm{p}=0.021 ; \mathrm{Fig}\right.$. 3$)$. Biting was not significantly affected by the water conditioner $\left(\mathrm{F}_{1,69}=0.138, \mathrm{p}=0.712\right)$ and did not differ over time $\left(\mathrm{F}_{3,69}=0.954\right.$, $\mathrm{p}=0.419$ ) (see supplementary information 1 ). Water conditioner and stage of transport did not significantly affect mortality, which was low throughout (Stress Coat ${ }^{\circledR}: F_{1,67}=0.377, p=0.541$; stage: $\left.\mathrm{F}_{3,67}=0.909, \mathrm{p}=0.441\right)$, ventilation rate (Stress Coat ${ }^{\circledR}: \mathrm{F}_{1,42}=1.709, \mathrm{p}=0.198$; stage: $\mathrm{F}_{3,42}=0.346$, $\mathrm{p}=0.709$ ), or injury (Stress Coat ${ }^{\circledR}: \mathrm{F}_{1,69}=0.125, \mathrm{p}=0.725$; stage: $\mathrm{F}_{3,69}=1.048, \mathrm{p}=0.377$ ) (see supplementary information 1). On arrival at the store, water conditioner did not significantly affect water $\mathrm{pH}(\mathrm{t}=1.214, \mathrm{df}=19.999, \mathrm{p}=0.239)$, dissolved oxygen $(\mathrm{t}=1.052, \mathrm{df}=10.603, \mathrm{p}=0.316)$, water temperature $(t=0.325, \mathrm{df}=18.815, \mathrm{p}=0.749)$, total ammonia nitrogen levels $(\mathrm{t}=1.071, \mathrm{df}=$ 19.641, $\mathrm{p}=0.297)$ or unionised ammonia levels $(\mathrm{t}=0.8275, \mathrm{df}=13.894, \mathrm{p}=0.422)($ see supplementary information 1). 
As in the regional study, erratic swimming was significantly affected by both the water conditioner $\left(\mathrm{F}_{1,88}=9.404, \mathrm{p}=0.003\right.$; Fig. 4$)$ and stage of transport $\left(\mathrm{F}_{3,88}=39.400, \mathrm{p}<0.001\right.$; Fig. 4). There was a significant interaction between the two factors $\left(\mathrm{F}_{3,88}=4.802, \mathrm{p}=0.004\right.$; Fig. 4). Erratic swimming was higher at the wholesaler than at the store and at this point in the transport chain there was no significant effect of water conditioner (Fig. 4). Erratic swimming behaviour decreased once fish were at the retail store which was lower on day 5 of recovery than on arrival (Fig. 4). Fish transported with water conditioner for the international part of the journey displayed significantly less erratic swimming on arrival at the store as seen in the regional study (Fig. 4). In contrast to the regional transport, chasing behaviour was significantly higher in the control group compared to the water conditioner group during recovery at both the wholesaler and the retail stores $\left(\mathrm{F}_{1,88}=11.55, \mathrm{p}<0.001\right.$; Fig. 5) with chasing generally higher in tanks than bags $\left(\mathrm{F}_{3,92}=12.717, \mathrm{p}<0.001 ;\right.$ Fig. 5). Biting was highest on day 5 of recovery at the store $\left(\mathrm{F}_{3,91}=12.317\right.$, $\mathrm{p}<0.001$; Fig. 6$)$ and was also significantly lower in the fish exposed to the water conditioner during international transport compared to controls $\left(F_{1,91}=8.234, p=0.03\right.$; Fig. 6$)$. Mortality remained low throughout and was not affected by the water conditioner treatment $\left(\mathrm{F}_{1,95}=0.412, \mathrm{p}=0.523\right)$. Neither transport stage nor treatment had a significant effect on ventilation rate (Stress Coat ${ }^{\mathbb{R}}: \mathrm{F}_{1,57}=3.104, \mathrm{p}=0.468$; stage: $\mathrm{F}_{3,57}=1.342, \mathrm{p}=0.269$ ) or injury (Stress Coat ${ }^{\circledR}: F_{1,42}=0.279, p=0.597$; stage: $F_{3,42}=4.167, p=0.062$ ) (see supplementary information 2). The effect of water conditioner on water quality was only tested on arrival at the wholesaler. The water conditioner did not significantly affect water $\mathrm{pH}(\mathrm{t}=1.366, \mathrm{df}=27.566, \mathrm{p}=0.183)$, dissolved oxygen $(t=0.298, d f=29.454, p=0.768)$, water temperature $(t=0.246, d f=30, p=0.807)$, total ammonia nitrogen levels $(t=1, d f=15, p=0.333)$ and unionised ammonia levels $(t=1, d f=15, p=$ 336 0.333) (see supplementary information 2). 
The aim of this study was to determine whether there are any benefits of adding water conditioner to the transport water of ornamental fishes, particularly in relation to welfare. Here, the commerciallyavailable water conditioner, Stress Coat ${ }^{\circledR}$ was tested in a simulated laboratory transport, and two durations of commercial transport. The effects of Stress Coat ${ }^{\mathbb{R}}$ were variable between studies, but overall the water conditioner appeared to cause reduced levels of erratic swimming and aggressive behaviour. The water conditioner had no effect on the water quality parameters measured. In the simulated transport, the water conditioner reduced biting levels during recovery post-transport. A reduction in biting was also seen when the water conditioner was added to the international component of the transport chain. For the international transport, as Stress Coat ${ }^{\circledR}$ was only added for the international leg of the journey, this suggests that the behavioural effects of Stress Coat ${ }^{\circledR}$ can persist for a period of time as effects were seen more on arrival at the store, rather than during time at the wholesaler. Although the water conditioner did significantly affect levels of biting in the international transport study, there was no significant difference in visible injuries which is perhaps not surprising as although statistically different between treatments, the level of biting overall was low.

Behavioural variation is a common welfare measure as deviation from natural behaviours can indicate an increase in stress, aggression and fear (Huntingford et al., 2006; Weber, 2011; Braithwaite and Ebbesson, 2014). Guppies are known to form shoals, but this behaviour is dynamic and contextdependent (Croft et al., 2003, 2006); for example when predation threat is low, shoaling decreases and hierarchies establish over resource competition. Formation of hierarchies in guppies involves biting and chasing behaviour (Gorlick, 1976; Magurran and Seghers, 1991). In contrast, there is little scientific literature on the social behaviour of variatus platy. They are generally considered peaceful fish, preferring to live in small groups (Beaugrand et al., 1984). While their social behaviour is not 
widely documented, hierarchy formation in other related species, such as the sword-tail (Xiphophorus helleri), involves threat displays which can escalate to chasing and then biting behaviours (Braddock, 1945; Scott and Currie, 1980). Behaviours associated with the establishment of hierarchies are not necessarily a sign of poor welfare as they form part of the natural behaviour repertoire of the species (Martins et al., 2012). However, once hierarchies are established, the persistence or escalation of chasing and biting behaviour becomes a welfare concern (Ashley, 2007; Huntingford et al., 2006). Biting in particular can result in injuries through physical contact (Ashley, 2007; Martins et al., 2012). Some levels of chasing and biting are likely unavoidable when ornamental fishes are placed in a new community following commercial transport while hierarchies are being established; although these behaviours are considered normal, they can still induce stress (Culbert and Gilmour, 2016; Spagnoli et al., 2016). Therefore, a reduction in chasing and biting behaviour as observed with the addition of the water conditioner is desirable as a more peaceful hierarchy establishment is likely to be less stressful for the fish.

No study has been found that measures changes in behaviour following transport of ornamental fishes, limiting comparison with existing literature. Some studies on aquaculture species have assessed changes in behaviour in response to transport. A study by Chandroo et al. (2005) analysed the activity levels of rainbow trout (Oncorhynchus mykiss) before, during and after transport and found that seven of 11 fish showed an elevation in activity levels during transport. Four fish showed a reduction in activity compared to baseline levels and all fish displayed some fast swimming. Although fast swimming was not further described by the authors, it may have been an example of erratic swimming. The display of erratic swimming is a common behavioural measure for stress in fishes (Conte, 2004; Håstein, 2004, White et al. 2017). Erratic swimming behaviour was elevated during live-haul boat transport of Atlantic salmon (Salmo salar), although this was site dependent (Nomura et al., 2009), but erratic swimming was supressed during recovery from transport in rainbow trout $(O$. mykiss) (Shabani et al., 2016). In the current study, the addition of water conditioner during both regional and international transport significantly reduced the occurrence of erratic swimming when fish were held in bags on arrival at the store, which could indicate that the fish were less stressed 
(Conte, 2004; Håstein, 2004, White et al., 2017). During a study on the cortisol response to stress,

390 Barton and Peter (1982) noticed an increase in erratic swimming when transporting fingerling rainbow trout (Salmo gairdneri) in water containing $0.5 \% \mathrm{NaCl}$. Although behavioural variation was not the focus of the study, the authors did note this change as an indication of elevated stress. Further studies are required to monitor variation in behaviour during and following transport

The concept of allostatic capacity may help explain the observed delay in erratic swimming reduction in the international transport trial as well as the difference in chasing behaviour between the regional transport and international transport trials. Allostasis is an animal's capacity to respond to a stressor without its welfare being compromised; whereby an animal's response to a prior stressor affects its ability to respond to subsequent stressors (McEwen and Wingfield, 2003; Braithwaite and Ebbesson, 2014; Sneddon et al., 2016). Although no reduction in stress-associated behaviours were observed on arrival and during recovery at the wholesaler in the international transport trial, fish exposed to Stress Coat ${ }^{\circledR}$ during international transport may have increased their allostatic capacity during transport/recovery at the wholesaler, resulting in better coping capabilities for the subsequent regional transport than fish transported under control conditions. This hypothesis requires further research; regardless, the lower levels of biting and chasing displayed by the fish exposed to water conditioner during international transport suggest improved welfare compared to fish transported without the water conditioner.

There was no significant effect of Stress Coat ${ }^{\circledR}$ on mortality, either during the regional or international transports. A study by Swanson et al. (1996) tested the effect of NovAqua ${ }^{\circledR}$ (Krodon) added to transport water on the survival of wild-caught delta smelt (Hypomesus transpacificus). NovAqua ${ }^{\circledR}$ is a polymer-based water conditioner and dechlorinator but no details about its composition are available. Swanson et al. (1996) found that the addition of NovAqua ${ }^{\circledR}$ to transport water significantly reduced mortality for $72 \mathrm{~h}$ after transport. Similarly, in studies using disease challenge where mortality is predicted to be high, beneficial effects of $A$. vera have been shown. For example, an increase in survival in common carp (Cyprinus carpio) fed a diet supplemented with $A$. vera $\left(5 \mathrm{~g} \mathrm{~kg}^{-1}\right.$ A. vera for 6 weeks) was found after a challenge with live Aeromonas hydrophila 
416 (Alishahi et al., 2010). The present study tested the effects of Stress Coat ${ }^{\circledR}$ during commercial

417 transport. Unlike Swanson et al. (1996) and Alishahi et al. (2010), we did not find a reduction in platy

418 mortality after Stress Coat ${ }^{\circledR}$ exposure. However, in our study mortality was low throughout.

419 Therefore, any potential of Stress Coat ${ }^{\circledR}$ to lower mortality would be difficult to identify within our 420 transport chain.

421 We also found no detectable effect of Stress Coat ${ }^{\mathbb{B}}$ on the number of body injuries that occurred, but again the total number of injuries remained low throughout. Aloe vera was found to improve the healing of wounds following handling for induced spawning (Zanuzzo et al., 2015b). Induced spawning, like many fish husbandry practices (including transport), involves handling and air exposure. Zanuzzo et al. (2015b) bathed matrinxã (Brycon amazonicus) for $24 \mathrm{~h}$ in water containing $0.1 \mathrm{~g}^{-1}$ A. vera following induced spawning and found that following recovery, fish exposed to $A$. vera had a higher number of epidermal goblet cells and improved wound healing rate than nonexposed fish. Addition of 0.2 and $2 \mathrm{mg} \mathrm{l}^{-1}$ of $A$. vera to water during transport also increased the activity of the immune system in matrinxã after they were handled, but this effect was no longer noticeable once transport ended (Zanuzzo et al. 2012). Similarly, dietary A. vera supplementation (5$20 \mathrm{mg} \mathrm{kg}^{-1}$ ) in pacu (Piaractus mesopotamicus) for 10 days prior to transport enhanced innate immune parameters immediately after transport compared to pacu fed a control diet (Zanuzzo et al., 2017). Due to the overall good physical condition of the fish in the present study, it cannot be determined whether the water conditioner improved healing in fish following transport.

\section{Conclusion}

Overall, adding Stress Coat ${ }^{\circledR}$ to the transport water of ornamental fish improved behavioural indicators of welfare with the biggest effects observed when the water conditioner was added to the international leg of a commercial transport chain. No study has been found that assessed the effect of pure $A$. vera on stress-associated behaviours in fish. Therefore, it is not possible to determine from this study if the observed improvements were a result of the $A$. vera in the Stress Coat ${ }^{\mathbb{R}}$ or if the 
improvements are a result of the various compounds present in Stress Coat ${ }^{\circledR}$ working in synergy. Further research is needed in this area and into the potential for water conditioners to enhance the welfare of fish transported for the ornamental trade.

\section{Acknowledgments}

We would like to thank the management and staff at the wholesaler and retail stores where data were collected. We would like to thank the laboratory technicians at the University of the West of Scotland for their support during sample processing, including Deirdre Galbraith and Edith Burns for help with fish husbandry. Many thanks to Dr Andisheh Bakhshi and Dr Mhairi Alexander for their support with experimental design and statistical analyses, and to Dr Lewis Eaton for comments on a previous version of the manuscript.

\section{Declaration of Interest}

This work was funded by Mars Petcare. The WALTHAM ${ }^{\circledR}$ Centre for Pet Nutrition is a fundamental research centre for Mars Petcare. Dr Donna Snellgrove was an employee of Mars Petcare during the study.

\section{References}

Alishahi, M., Ranjbar, M.M., Ghorbanpour, M., Peyghan, R., Mesbah, M., Razi jalani, M., 2010. Effects of dietary Aloe vera on some specific and nonspecific immunity in the common carp (Cyprinus carpio). International Journal of Veterinary Research 4(3), 189-195.

\section{https://doi.org/10.22059/ijvm.2010.21352}

Alvarenga, C.M.D., Volpato, G.L., 1995. Agonistic profile and metabolism in alevins of the Nile tilapia. Physiology \& Behavior 57(1), 75-80. https://doi.org/10.1016/0031-9384(94)00206-K 
Azambuja, C.R., Mattiazzi, J., Riffel, A.P.K., Finamor, I.A., de Oliveira Garcia, L., Heldwein,

C.G., Heinzmann, B.M., Baldisserotto, B., Pavanato, M.A., Llesuy, S.F., 2011. Effect of the essential

oil of Lippia alba on oxidative stress parameters in silver catfish (Rhamdia quelen) subjected to

transport. Aquaculture 319(1-2), 156-161. https://doi.org/10.1016/j.aquaculture.2011.06.002

Barreto, R.E., Volpato, G.L., 2011. Ventilation rates indicate stress-coping styles in Nile tilapia.

Salmo gairdneri Richardson, to various transport conditions, anaesthesia, and cold shock. Journal of

Fish Biology 20, 39-51. https://doi.org/10.1111/j.1095-8649.1982.tb03893.x

Bates, D., Mächler, M., Bolker, B., Walker, S., 2015. Fitting linear mixed-effects models using

lme4. Journal of Statistical Software 67(1), 1-48. https://doi.org/10.18637/jss.v067.i01 
the essential oil of Lippia alba. Fish Physiology and Biochemistry 38(3), 789-796.

\section{https://doi.org/10.1007/s10695-011-9562-4}

Becker, A.G., Parodi, T. V., Zeppenfeld, C.C., Salbego, J., Cunha, M.A., Heldwein, C.G., Loro, V.L., Heinzmann, B.M., Baldisserotto, B., 2016. Pre-sedation and transport of Rhamdia quelen in water containing essential oil of Lippia alba: metabolic and physiological responses. Fish Physiology and Biochemistry 42(1), 73-81. https://doi.org/10.1007/s10695-015-0118-X

Bolker, B.M., Brooks, M.E., Clark, C.J., Geange, S.W., Poulsen, J.R., Stevens, M.H.H., White, J.S.S., 2009. Generalized linear mixed models: a practical guide for ecology and evolution. Trends in Ecology \& Evolution 24(3), 127-135. https://doi.org/10.1016/j.tree.2008.10.008

Bower, C.E., Holm-Hansen, T., 1980. A salicylate-hypochlorite method for determining ammonia in seawater. Canadian Journal of Fisheries and Aquatic Sciences 37(5), 794-798. https://doi.org/10.1139/f80-106

Braddock, J.C., 1945. Some aspects of the dominance-subordination relationship in the fish Platypoecilus maculatus. Physiological Zoology 18, 176-195.

https://doi.org/10.1086/physzool.18.2.30151863

Braithwaite, V.A., Ebbesson, L.O.E., 2014. Pain and stress responses in farmed fish. Revue Scientifique et Technique Office International de Epizootics 33, 245-253.

California Water Boards Agency, 2011. Formulas used to derive un-ionized ammonia fractions and US EPA ammonia criteria.

https://www.waterboards.ca.gov/waterrights/water_issues/programs/bay_delta/docs/cmnt081712/srcs d/engleatt2.pdf (Accessed 23 $3^{\text {rd }}$ March 2019)

Chandroo, K.P., Cooke, S.J., McKinley, R.S., Moccia, R.D., 2005. Use of electromyogram telemetry to assess the behavioural and energetic responses of rainbow trout, Oncorhynchus mykiss (Walbaum) to transportation stress. Aquaculture Research 36, 1226-1238. 

their biologic effects. Seminars in Integrative Medicine 1(1), 53-62. https://doi.org/10.1016/S1543$\underline{1150(03) 00005-X}$

Christaki, E., Florou-Paneri, P., 2010. Aloe vera : a plant for many uses. Journal of Food, Agriculture and Environment 8(2), 245-249.

Colburn, N.N., Qiang, J., He, J., Ma, X.Y., Kpundeh, M.D., Xu, P., 2015a. Dietary Aloe vera supplementation on growth performance, some haemato-biochemical parameters and disease resistance against Streptococcus iniae in tilapia (GIFT). Fish \& Shellfish Immunology 44(2), 504-

Colburn, H.R., Walker, A.B., Berlinsky, D.L., Nardi, G.C., 2008. Factors affecting survival of cobia, Rachycentron canadum, during simulated transport. Journal of the World Aquaculture Society 39(5), 678-683. https://doi.org/10.1111/j.1749-7345.2008.00205.x subordination in rainbow trout. Physiology \& Behavior 164, 306-313. 

in AQUI-S 20E (10\% eugenol) at high loading densities. North American Journal of Aquaculture 79(2), 176-182. https://doi.org/10.1080/15222055.2017.1281853

Deng, Z., Guensch, G.R., McKinstry, C. A, Mueller, R.P., Dauble, D.D., Richmond, M.C., 2005. Evaluation of fish-injury mechanisms during exposure to turbulent shear flow. Canadian Journal of Fisheries and Aquatic Sciences 62(7), 1513-1522. https://doi.org/10.1139/f05-091

2006. Social interactions tune aggression and stress responsiveness in a territorial cichlid fish

(Archocentrus nigrofasciatus). Physiology \& Behavior 88(4-5), 353-363.

Fox, J., Weisberg, S., 2011. An R companion to applied regression, 2nd Ed. Sage Publications, Thousand Oaks, CA.

Friard, O., Gamba, M., 2016. BORIS: a free, versatile open-source event-logging software for video/audio coding and live observations. Methods in Ecology and Evolution 7(11), 1325-1330. https://doi.org/10.1111/2041-210X.12584

Gabriel, N.N., Qiang, J., He, J., Ma, X.Y., Kpundeh, M.D. and Xu, P., 2015a. Dietary Aloe vera supplementation on growth performance, some haemato-biochemical parameters and disease resistance against Streptococcus iniae in tilapia (GIFT). Fish \& Shellfish Immunology 44(2), 504-514. https://doi.org/10.1016/j.fsi.2015.03.002 
Poecilia reticulata (Peters). Animal Behaviour 24, 336-346. https://doi.org/10.1016/S0003-

Gronquist, D., Berges, J.A., 2013. Effects of aquarium-related stressors on the zebrafish: a

comparison of behavioral, physiological, and biochemical indicators. Journal of Aquatic Animal

Health 25(1), 53-65. https://doi.org/10.1080/08997659.2012.747450

Hamman, J.H., 2008. Composition and applications of Aloe vera leaf gel. Molecules 13(8),

1599-1616. https://doi.org/10.3390/molecules13081599

Harmon, T.S., 2009. Methods for reducing stressors and maintaining water quality associated

with live fish transport in tanks: a review of the basics. Reviews in Aquaculture 1(1), 58-66.

https://doi.org/10.1111/j.1753-5131.2008.01003.x

Harnish, R.A., Colotelo, A.H., Brown, R.S., 2011. A review of polymer-based water

conditioners for reduction of handling-related injury. Reviews in Fish Biology and Fisheries 21(1),

43-49. https://doi.org/10.1007/s11160-010-9187-1

Håstein, T., 2004. Animal welfare issues relating to aquaculture. Global Conference on Animal

Welfare: an OIE Initiative. Paris, France.

http://citeseerx.ist.psu.edu/viewdoc/download?doi=10.1.1.135.2685\&rep=rep1\&type=pdf\#page=221 

$\underline{1 \& \text { isAllowed }=y}$ (Accessed 23 $3^{\text {rd }}$ March 2019).

Inoue, L.A.K.A., Afonso, L.O.B., Iwama, G.K. and Moraes, G., 2005. Effects of clove oil on the stress response of matrinxã (Brycon cephalus) subjected to transport. Acta Amazonica 35(2), 289295.

Iversen, M., Eliassen, R.A., Finstad, B., 2009. Potential benefit of clove oil sedation on animal welfare during salmon smolt, Salmo salar L. transport and transfer to sea. Aquaculture Research 40(2), 233-241. https://doi.org/10.1111/j.1365-2109.2008.02091.x

Javahery, S., Nekoubin, H., Moradlu, A.H., 2012. Effect of anaesthesia with clove oil in fish (review). Fish Physiology and Biochemistry 38(6), 1545-1552. https://doi.org/10.1007/s10695-012$\underline{9682-5}$

Kadry, V.O., Barreto, R.E., 2010. Environmental enrichment reduces aggression of pearl cichlid, Geophagus brasiliensis, during resident-intruder interactions. Neotropical Ichthyology 8(2), 329-332. https://doi.org/10.1590/S1679-62252010000200011

Kaiser, B.H., Brill, G., Cahill, J., Collett, P., Czypionka, K., Green, A., Orr, K., Pattrick, P., Scheepers, R., Stonier, T., Whitehead, M.A., Yearsley, R., 2006. Testing clove oil as an anaesthetic for long-distance transport of live fish : the case of the lake Victoria cichlid Haplochromis obliquidens. Journal of Applied Ichthyology 22(6), 510-514. https://doi.org/10.1111/j.14390426.2006.00786.x

Kalueff, A.V., Gebhardt, M., Stewart, A.M., Cachat, J.M., Brimmer, M., Chawla, J.S., Craddock, C., Kyzar, E.J., Roth, A., Landsman, S., Gaikwad, S., 2013. Towards a comprehensive catalog of zebrafish behavior 1.0 and beyond. Zebrafish 10(1), 70-86.

Lenth, R. V, 2017. Least-squares means: the R package lsmeans. Journal of Statistical Software 69, 1-33. https://doi.org/10.18637/jss.v069.i01 

ornamental fish packaging systems for air transport. Aquaculture Research 34(11), 923-935.

(Poecilia reticulata) populations in Trinidad. Behaviour 118, 214-234.

Mars Fishcare, 2014. Stress Coat NG. https://www.apifishcare.com/pdf/API_STRESS_COAT-

Monticini, P., 2010. The ornamental fish trade - production and commerce of ornamental fish: technical-managerial and legislative aspects. Food and Agriculture Organization of the United Nations. Globefish Research Program 102, 134. http://www.fao.org/3/a-bb206e.pdf (Accessed 23 ${ }^{\text {rd }}$ March 2019). Abernethy, C.S., Amidan, B., 2004. Survival estimates for juvenile fish subjected to a laboratorygenerated shear environment. Transactions of the American Fisheries Society 133(2), 447-454. https://doi.org/Doi 10.1577/02-021 
Cottee, S.Y., 2012. Injuries and deformities in fish: their potential impacts upon aquacultural mixed effects models. R package version 3 . 1468482610,9781468482614

Portz, D.E., Woodley, C.M., Cech, J.J., 2006. Stress-associated impacts of short-term holding on fishes. Reviews in Fish Biology and Fisheries 16(2), 125-170. https://doi.org/10.1007/s11160-006$\underline{9012-\mathrm{Z}}$ project.org/

R Studio Team, 2016. RStudio: integrated development environment for R. 5(1), 21-26. https://doi.org/10.1016/j.jtcme.2014.10.006 as aversive? PLoS One 8 e73773. https://doi.org/10.1371/journal.pone.0073773 net-caught fish in the aquarium trade. SPC Live Reef Fish Information Bulletin 13, 13-23. 
660 Loro, V.L., Schetinger, M.R.C., Morsch, V.M., Heinzmann, B.M., Baldisserotto, B., 2014. The

essential oil from Lippia alba induces biochemical stress in the silver catfish (Rhamdia quelen) after Animal Behaviour Science 125(3-4), 195-205. Xiphophorus helleri Heckel. Journal of Fish Biology 16, 265-277. https://doi.org/10.1111/j.1095$\underline{8649.1980 . t b 03704 . x}$

Elsevier Inc., London, UK, pp. 463-539. https://doi.org/10.1016/B978-0-12-802728-8.00012-6 

physiology. Elsevier Inc., pp. 541-564. https://doi.org/10.1016/B978-0-12-802728-8.00013-8

K.A., 2019. The use of feed and water additives for live fish transport. Reviews in Aquaculture 11(1), color pattern and insulin-like growth factor-I gene expression in Nile tilapia, Oreochromis niloticus. Hormones and Behavior 51(5), 611-619. https://doi.org/10.1016/j.yhbeh.2007.02.010 of North America - Exotic Animal Practice 14, 21-32. https://doi.org/10.1016/j.cvex.2010.09.002 improvement of the respiratory activity of leukocytes of matrinxã during the transport stress. Revista Brasileira de Zootecnia 41(10), 2299-2302. https://doi.org/10.1590/S1516-35982012001000023 
combined heat killed Aeromonas hydrophila infection. Fish Shellfish Immunology 65, 198-205. https://doi.org/10.1016/j.fsi.2017.04.013

711 Oncorhynchus mykiss metabolic rate is affected by dietary Aloe vera inclusion but not by mounting an 712 immune response against formalin-killed Aeromonas salmonicida. Journal of Fish Biology 87(1), 43713 53. https://doi.org/10.1111/jfb. 12690

714 Zanuzzo, F.S., Zaiden, S.F., Senhorini, J.A., Marzocchi-Machado, C.M., Urbinati, E.C., 2015 b.

715 Aloe vera bathing improved physical and humoral protection in breeding stock after induced

716 spawning in matrinxã (Brycon amazonicus). Fish Shellfish Immunology 45(1), 132-140.

717 https://doi.org/10.1016/j.fsi.2015.02.017 


\section{Figure Captions}

Figure 1: Biting Behaviour Following Simulated Transport. The occurrence of biting posttransport for fish transported with and without the addition of water conditioner. Data are mean (diamond), median, upper and lower 25 th percentile, and outliers, $n=6$.

Figure 2: Erratic Swimming Behaviour Following Addition of Water Conditioner

During Regional Transport. The occurrence of erratic swimming behaviour for fish transported with and without the addition of water conditioner across different stages of commercial transport. Data are mean (diamond), median, upper and lower 25th percentile, and outliers, $n=11$. Asterisk indicates a significant difference between treatments within a specific time point (post-hoc Tukey, $\mathrm{p}<0.05$ ). Letters indicate differences between specific time points where boxes sharing a letter are not significantly different (post-hoc Tukey, $\mathrm{p}<0.05)$.

Figure 3: Chasing Behaviour Following Addition of Water Conditioner During Regional Transport. The occurrence of chasing behaviour for fish transported with and without the addition of water conditioner across different stages of commercial transport. Data are mean (diamond), median, upper and lower 25 th percentile, and outliers, $n=11$. Asterisk indicates a significant difference between treatments within a specific time point (post-hoc Tukey, $\mathrm{p}<0.05)$. Letters indicate differences between specific time points where boxes sharing a letter are not significantly different (post-hoc Tukey, $\mathrm{p}<0.05$ ). During International Transport. The occurrence of erratic swimming behaviour for fish transported with and without the addition of water conditioner across different stages of commercial transport. Data are mean (diamond), median, upper and lower 25th percentile, and outliers, $n=16$. Asterisk indicates a significant difference between treatments within a 
specific time point (post-hoc Tukey, $\mathrm{p}<0.05$ ). Letters indicate differences between specific time points where boxes sharing a letter are not significantly different (post-hoc Tukey, $\mathrm{p}<0.05)$.

Figure 5: Chasing Behaviour Following Addition of Water Conditioner During International Transport. The occurrence of chasing behaviour for fish transported with and without the addition of water conditioner across different stages of commercial transport. Data are mean (diamond), median, upper and lower 25th percentile, and outliers, $n=16$. Asterisk indicates a significant difference between treatments within a specific time point (post-hoc Tukey, $\mathrm{p}<0.05$ ). Letters indicate differences between specific time points where boxes sharing a letter are not significantly different (post-hoc Tukey, $\mathrm{p}<0.05$ ).

\section{Figure 6: Biting Behaviour Following Addition of Water Conditioner During}

761 International Transport. The occurrence of biting behaviour for fish transported with and without the addition of water conditioner across different stages of commercial transport. Data are mean (diamond), median, upper and lower 25th percentile, and outliers, $n=16$. Asterisk indicates a significant difference between treatments within a specific time point (post-hoc Tukey, $\mathrm{p}<0.05$ ). Letters indicate differences between specific time points where boxes sharing a letter are not significantly different (post-hoc Tukey, $\mathrm{p}<0.05$ ). 


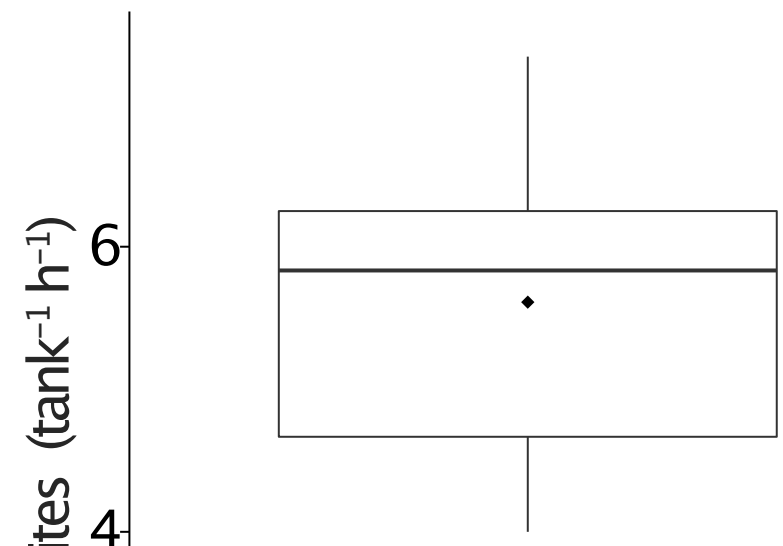


$773 \quad$ Figure 2

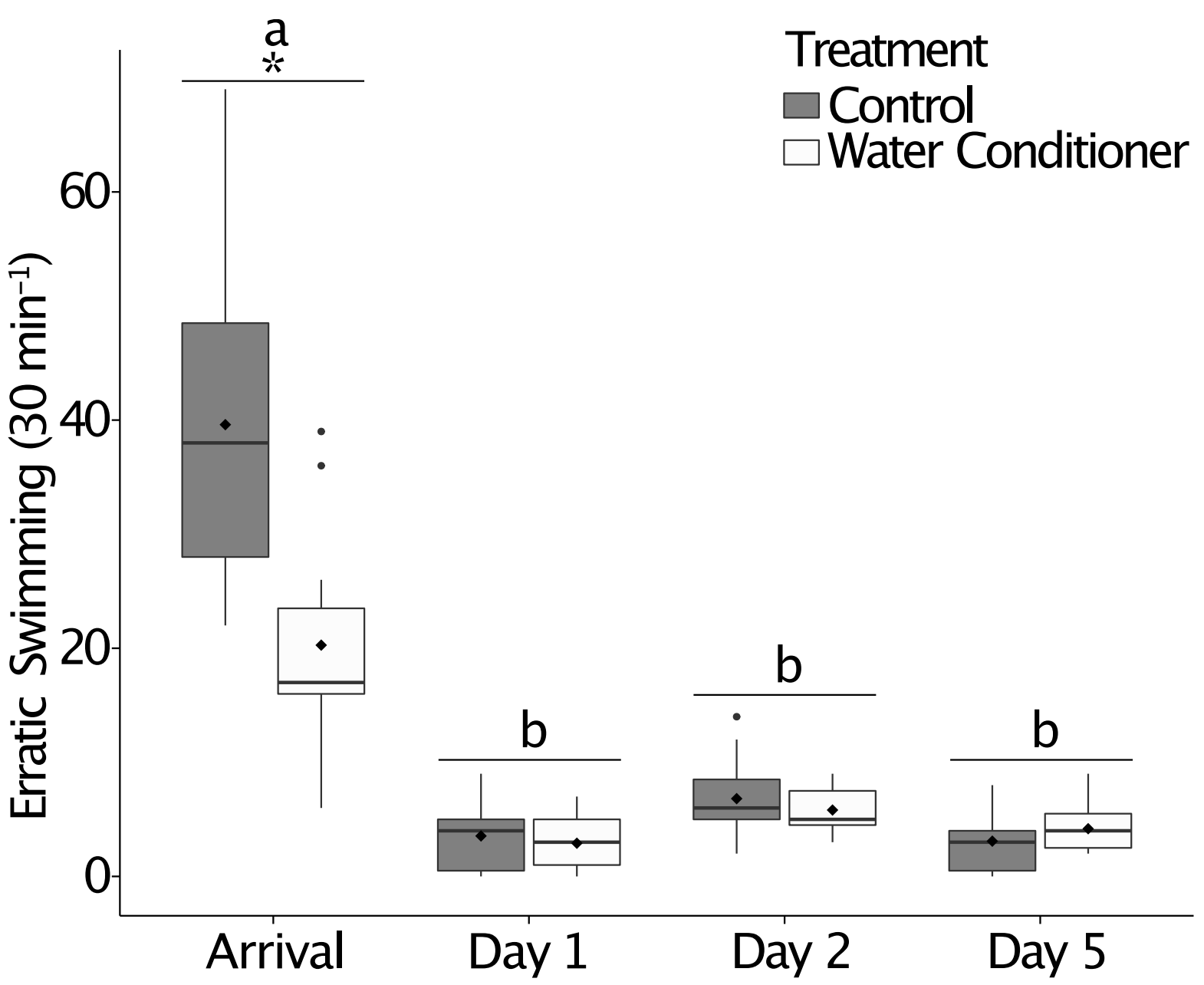


$776 \quad$ Figure 3

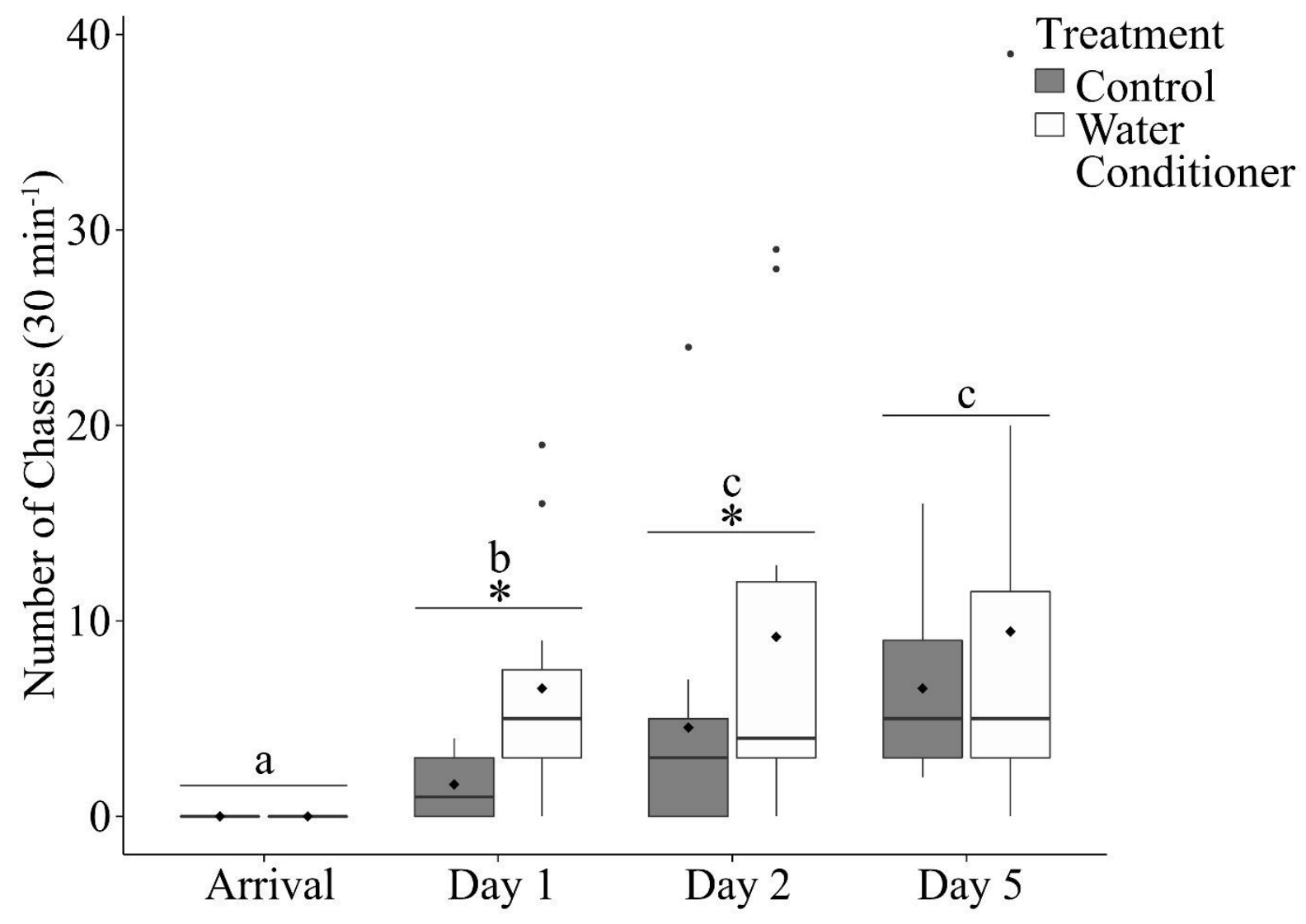


778 Figure 4

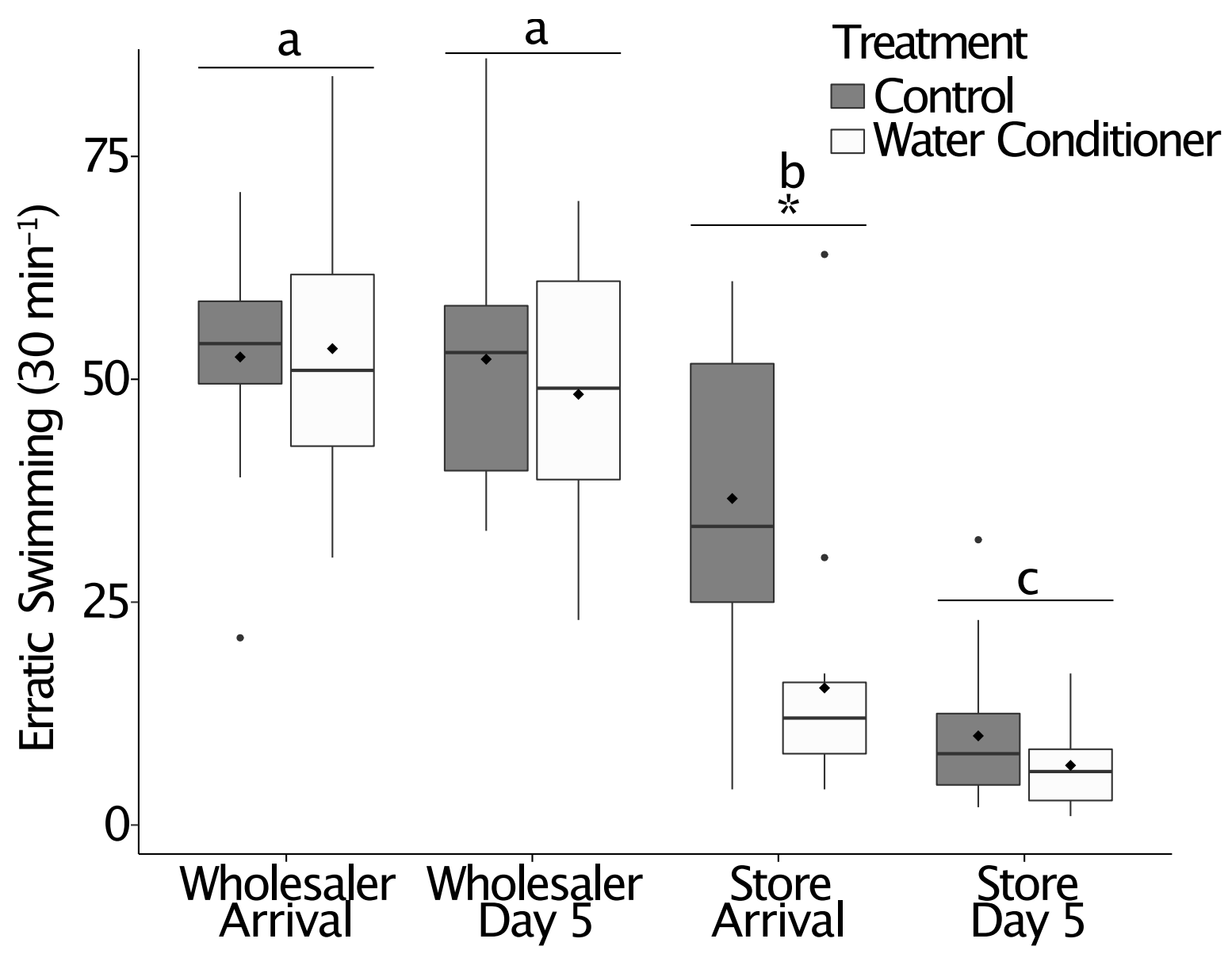


781 Figure 5

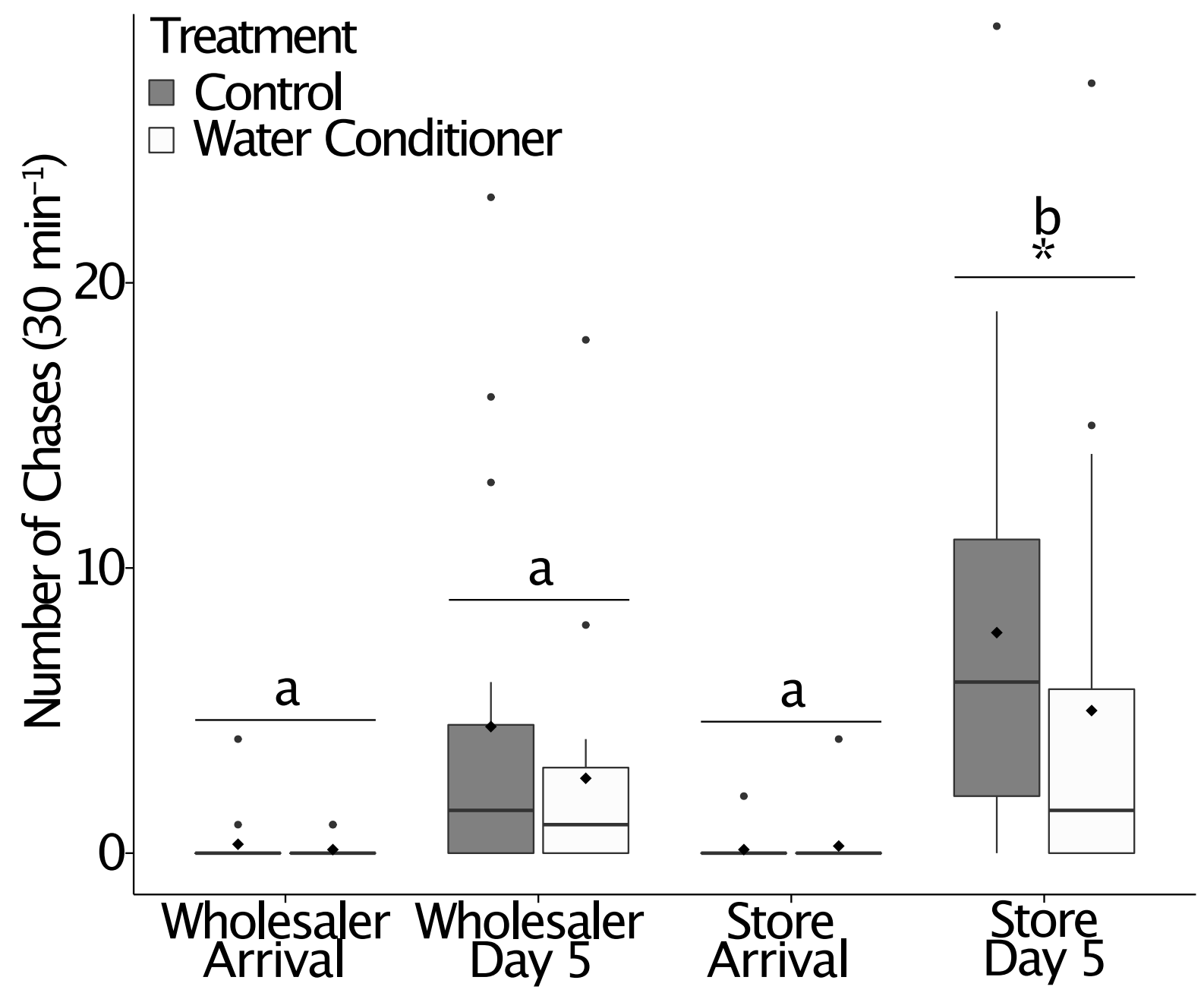


$783 \quad$ Figure 6

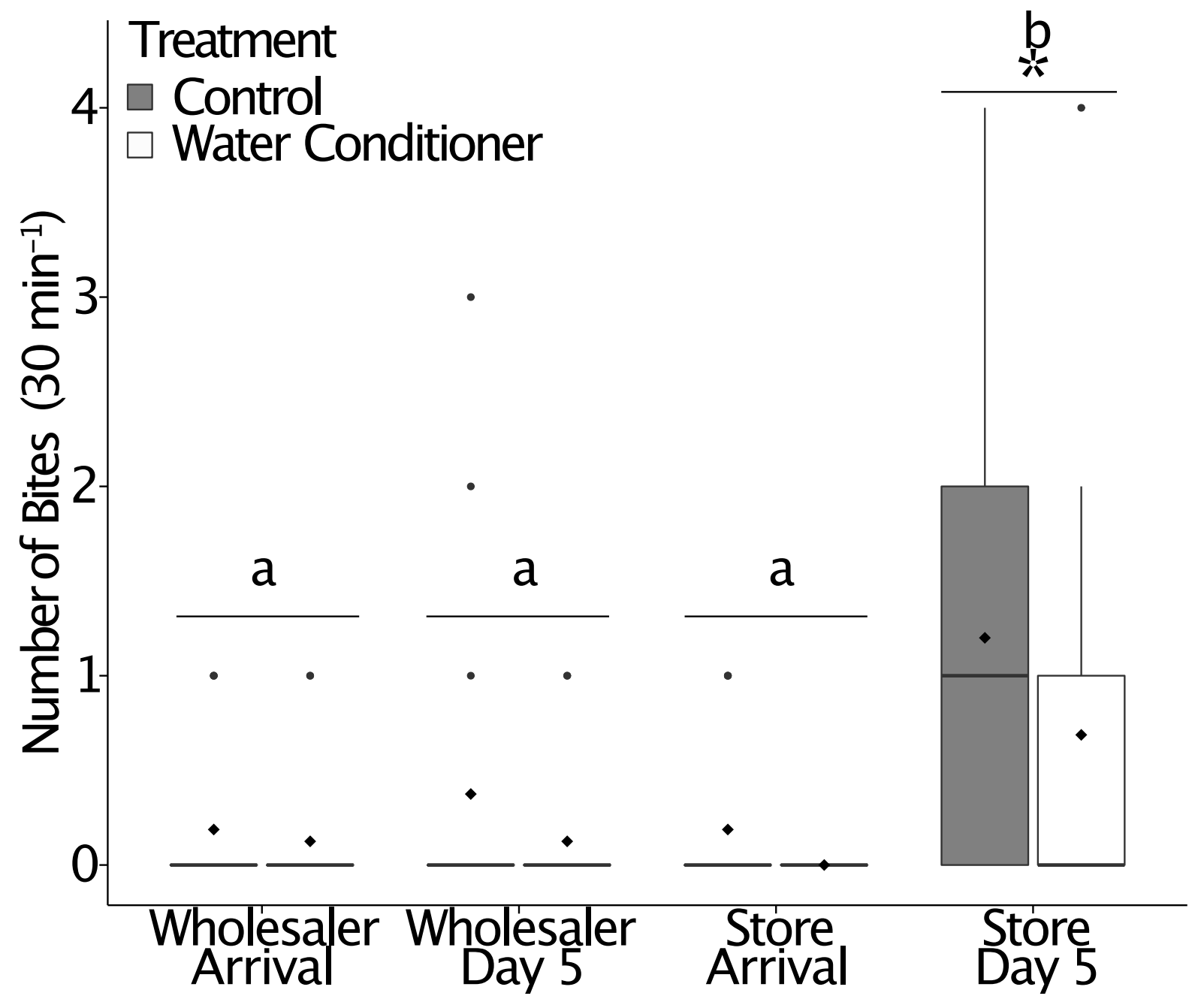


785 Supplementary information 1: Mean $( \pm \mathrm{SD})$ for regional transport trial.

\begin{tabular}{|c|c|c|c|c|c|c|c|c|}
\hline Stage & Treatment & $\mathrm{pH}$ & $\begin{array}{l}\text { Dissolved } \\
\text { oxygen }(\%)\end{array}$ & $\begin{array}{l}\text { Temperature } \\
\left({ }^{\mathrm{o}} \mathrm{C}\right)\end{array}$ & $\begin{array}{l}\text { TAN } \\
(\mathrm{ppm})\end{array}$ & $\begin{array}{l}\mathrm{NH}_{3} \\
(\mathrm{ppb})\end{array}$ & $\begin{array}{ll}\text { Biting } & \text { Ventilation } \\
\left(30 \mathrm{~min}^{-1}\right) & \text { rate } \min ^{-1}\end{array}$ & $\begin{array}{l}\text { Injury } \\
\left(30 \mathrm{~min}^{-1}\right)\end{array}$ \\
\hline Arrival & Control & $6.43( \pm 0.39)$ & $245.83( \pm 7.21)$ & $19.32( \pm 1.32)$ & $0.34( \pm 0.21)$ & $0.3( \pm 0.3)$ & $0.40( \pm 0.52) \quad \mathrm{N} / \mathrm{A}^{*}$ & $0( \pm 0)$ \\
\hline Arrival & $\begin{array}{l}\text { Water } \\
\text { conditioner }\end{array}$ & $6.64( \pm 0.40)$ & $232.46( \pm 41.49)$ & $19.48( \pm 1.02)$ & $0.25( \pm 0.18)$ & $0.5( \pm 0.7)$ & $1.09( \pm 3.01) \quad \mathrm{N} / \mathrm{A}^{*}$ & $0( \pm 0)$ \\
\hline Day 1 & Control & $6.25( \pm 0.74)$ & $104.7( \pm 1.48)$ & $18.48( \pm 1.48)$ & $0.03( \pm 0.04)$ & $\begin{array}{l}<0.01 \\
( \pm 0.01)\end{array}$ & $1.09( \pm 1.76) 70.69( \pm 16.37)$ & $0.18( \pm 0.6)$ \\
\hline Day 1 & $\begin{array}{l}\text { Water } \\
\text { conditioner }\end{array}$ & $6.16( \pm 0.57)$ & $104.04( \pm 2.67)$ & $18.37( \pm 1.28)$ & $0.03( \pm 0.03)$ & $0.01( \pm 0.01)$ & $0.82( \pm 1.66) 74.07( \pm 11.40)$ & $0.27( \pm 0.65)$ \\
\hline Day 2 & Control & $5.97( \pm 0.69)$ & $103.53( \pm 2.18)$ & $18.75( \pm 1.9)$ & $0.04( \pm 0.05)$ & $0.01( \pm 0.01)$ & $1.45( \pm 1.21) 67.06( \pm 13.98)$ & $0.09( \pm 0.30)$ \\
\hline Day 2 & $\begin{array}{l}\text { Water } \\
\text { conditioner }\end{array}$ & $6.13( \pm 0.72)$ & $104.74( \pm 3.16)$ & $18.72( \pm 1.87)$ & $0.04( \pm 0.06)$ & $0.01( \pm 0.01)$ & $1.90( \pm 3.27) 72.29( \pm 15.99)$ & $0( \pm 0)$ \\
\hline Day 5 & Control & $6.24( \pm 0.69)$ & $104.97( \pm 2.17)$ & $18.62( \pm 1.51)$ & $0.03( \pm 0.04)$ & $0.01( \pm 0.1)$ & $1.00( \pm 1.55) 70.00( \pm 12.48)$ & $0.18( \pm 0.60)$ \\
\hline Day 5 & $\begin{array}{l}\text { Water } \\
\text { conditioner }\end{array}$ & $6.15( \pm 0.71)$ & $104.69( \pm 2.17)$ & $18.62( \pm 1.3)$ & $0.03( \pm 0.04)$ & $0.01( \pm 0.1)$ & $0.82( \pm 1.25) 77.26( \pm 17.02)$ & $0.27( \pm 0.90)$ \\
\hline
\end{tabular}


Supplementary information 2: Mean \pm SD for international transport trial.

\begin{tabular}{|c|c|c|c|c|c|c|c|c|}
\hline Stage & Treatment & $\mathrm{pH}$ & $\begin{array}{l}\text { Dissolved oxygen } \\
(\%)\end{array}$ & $\begin{array}{l}\text { Temperature } \\
\left({ }^{\mathrm{o}} \mathrm{C}\right)\end{array}$ & $\begin{array}{l}\text { TAN } \\
(\mathrm{ppm})\end{array}$ & $\begin{array}{l}\mathrm{NH}_{3} \\
(\mathrm{ppb})\end{array}$ & $\begin{array}{l}\text { Ventilation } \\
\text { rate } \min ^{-1}\end{array}$ & $\begin{array}{l}\text { Injury } \\
\left(30 \mathrm{~min}^{-1}\right)\end{array}$ \\
\hline $\begin{array}{l}\text { Wholesaler } \\
\text { arrival }\end{array}$ & Control & $6.15( \pm 0.19)$ & $159.73( \pm 35.52)$ & $23.40( \pm 1.08)$ & $\begin{array}{l}0.00001 \\
( \pm 0.00001)\end{array}$ & $<0.01( \pm 0.01)$ & $\mathrm{N} / \mathrm{A}^{*}$ & $\mathrm{~N} / \mathrm{A}^{*}$ \\
\hline $\begin{array}{l}\text { Wholesaler } \\
\text { arrival }\end{array}$ & $\begin{array}{l}\text { Water } \\
\text { conditioner }\end{array}$ & $6.23( \pm 0.14)$ & $163.77( \pm 40.73)$ & $23.49( \pm 1.07)$ & $0.008( \pm 0.030)$ & $<0.01( \pm 0.02)$ & N/A* & $\mathrm{N} / \mathrm{A}^{*}$ \\
\hline $\begin{array}{l}\text { Wholesaler } \\
\text { day } 5\end{array}$ & Control & $6.67( \pm 0.43)$ & $96.94( \pm 3.33)$ & $23.62( \pm 1.21)$ & $0.47( \pm 0.77)$ & $1.1( \pm 2)$ & $\begin{array}{l}128.04 \\
( \pm 15.05)\end{array}$ & $\mathrm{N} / \mathrm{A}^{*}$ \\
\hline $\begin{array}{l}\text { Wholesaler } \\
\text { day } 5\end{array}$ & $\begin{array}{l}\text { Water } \\
\text { conditioner }\end{array}$ & $6.58( \pm 0.44)$ & $96.34( \pm 2.12)$ & $23.55( \pm 1.01)$ & $0.27( \pm 0.49)$ & $0.2( \pm 0.4)$ & $\begin{array}{l}115.90 \\
( \pm 16.33)\end{array}$ & $\mathrm{N} / \mathrm{A}^{*}$ \\
\hline $\begin{array}{l}\text { Store } \\
\text { arrival }\end{array}$ & Control & $6.77( \pm 0.24)$ & $227.27( \pm 40.51)$ & $18.71( \pm 1.87)$ & $0.39( \pm 0.60)$ & $0.6( \pm 0.7)$ & $\begin{array}{l}106.75 \\
( \pm 27.13)\end{array}$ & $0.19( \pm 0.54)$ \\
\hline $\begin{array}{l}\text { Store } \\
\text { arrival }\end{array}$ & $\begin{array}{l}\text { Water } \\
\text { conditioner }\end{array}$ & $6.81( \pm 0.30)$ & $233.29( \pm 29.64)$ & $18.45( \pm 1.93)$ & $0.40( \pm 0.47)$ & $0.7( \pm 0.8)$ & $\begin{array}{l}105.98 \\
( \pm 22.65)\end{array}$ & $0.31( \pm 0.70)$ \\
\hline Store day 5 & Control & $6.90( \pm 0.27)$ & $99.78( \pm 1.89)$ & $18.05( \pm 1.87)$ & $0.26( \pm 0.43)$ & $0.5( \pm 0.8)$ & $\begin{array}{l}117.41 \\
( \pm 19.93)\end{array}$ & $0.94( \pm 2.14)$ \\
\hline Store day 5 & $\begin{array}{l}\text { Water } \\
\text { conditioner }\end{array}$ & $6.78( \pm 0.33)$ & $100.14( \pm 2.37)$ & $17.80( \pm 1.75)$ & $0.28( \pm 0.50)$ & $0.4( \pm 0.8)$ & $\begin{array}{l}108.68 \\
( \pm 22.37)\end{array}$ & $0.44( \pm 0.81)$ \\
\hline
\end{tabular}

